Research Paper

\title{
In Vitro Anti-proliferative and Anti-invasive Effect of Polysaccharide-rich Extracts from Trametes Versicolor and Grifola Frondosa in Colon Cancer Cells
}

\author{
Daniel Roca-Lema ${ }^{*}$, Olaia Martinez-Iglesias ${ }^{1 *}$, Catalina Fernández de Ana Portela ${ }^{2}$, Arturo \\ Rodríguez-Blanco ${ }^{2}$, Manuel Valladares-Ayerbes ${ }^{3}$, Andrea Díaz-Díaz ${ }^{1}$, Alba Casas-Pais ${ }^{1}$, Cecilia Prego ${ }^{4}$ and \\ Angélica Figueroa ${ }^{\square}$ \\ 1. Epithelial Plasticity and Metastasis Group, Instituto de Investigación Biomédica de A Coruña (INIBIC), Complexo Hospitalario Universitario de A Coruña \\ (CHUAC), Sergas. Universidade da Coruña (UDC). \\ 2. Hifas da Terra SL, Pontevedra, Spain. \\ 3. Department of Medical Oncology, Hospital Universitario Reina Sofía, Córdoba, Spain. \\ 4. CZ Veterinaria SA, Pontevedra, Spain. \\ *These authors contributed equally to this work.
}

$\triangle$ Corresponding author: Angélica Figueroa, Epithelial Plasticity and Metastasis Group, Instituto de Investigación Biomédica (INIBIC), Complejo Hospitalario Universitario A Coruña (CHUAC), Sergas. Universidade da Coruña (UDC). As Xubias, 15006, A Coruña, Spain. Ph: +34-981-176399. angelica.figueroa.conde-valvis@sergas.es

(c) Ivyspring International Publisher. This is an open access article distributed under the terms of the Creative Commons Attribution (CC BY-NC) license (https://creativecommons.org/licenses/by-nc/4.0/). See http://ivyspring.com/terms for full terms and conditions.

Received: 2018.07.27; Accepted: 2018.11.05; Published: 2019.01.01

\begin{abstract}
Colorectal cancer (CRC) is one of leading causes of mortality in western countries and novel treatment strategies are required. The medicinal application of mushrooms has been used in traditional medicine in many oriental countries. Polysaccharide-rich extracts obtained from certain medicinal mushroom species have shown antitumor effects in different experimental models. In the present study, we have developed polysaccharide-rich extracts from Trametes versicolor (TV) and Grifola frondosa (GF) fruit bodies. We aim to evaluate the anticancer effects of these polysaccharide-rich extracts in LoVo and HT-29 human colon cancer cells. The in vitro effects were determined by cytotoxicity assay, proliferation assay, wound healing assay and invasion assay. Moreover, the effect on anchorage independent-cell growth was also determined. Our results showed that TV and GF extracts did inhibit human colon cell proliferation and induce cytotoxicity. Furthermore, both fungal extracts significantly inhibited oncogenic potential, cell migration and invasion in colon cancer cells. In addition, extracts induce a more epithelial phenotype, observed by phase contrast images, together with an increase expression of the E-cadherin epithelial marker, detected by western-blotting analyses. Moreover, by using gelatin zymography assays, it was detected a decrease of MMP-2 enzyme activity, a crucial metalloproteinase important for the degradation of the extracellular matrix. Finally, the combination of the extracts with one the most clinical used agents for colorectal cancer, 5 -fluorouracil, increases cell cytotoxicity. Taken together our results underscore a potential antitumor effect of polysaccharide-rich extracts obtained from TV and GF in human colon cancer cells lines. These finding may contribute to the reported health effects of fungal extracts.
\end{abstract}

Key words: Colon cancer, invasion, proliferation, Fugal extracts

\section{Introduction}

Colorectal cancer (CRC) is one of the leading causes of mortality in Western countries [1, 2]. Around $90 \%$ of cancer-related deaths are due to metastasis [3]. The metastatic process is constituted of a number of sequential events required in order for the tumour cell to successfully metastasize. In the 
metastatic cascade, epithelial cells detach from the primary tumour, migrate, acquire the ability to invade and spread throughout the body to finally settle down in a second site. During this metastatic cascade, other important changes take place such as the alteration of cell-cell contacts and cell-matrix adhesions.

Complementary and alternative medicines have appeared as a promising strategy to treat a broad number of diseases. Indeed, natural products are emerging as potent sources for food supplements to improve cancer outcomes and patient quality of life [4]. Important research lines of evidences have demonstrated that medicinal mushrooms have a potent anti-neoplastic activity, including anti-proliferative and anti-angiogenesis properties. It has been reported that certain species of higher Basidomycetes, including Trametes versicolor (TV) and Grifola frondosa (GF), produce several metabolites with anti-proliferative, antioxidant, antiviral, antimicrobial and immunomodulatory therapeutic effects $[5,6]$.

Grifola frondosa is an edible mushroom with an established immunological effect. Indeed, it has already been reported the effect of GF extracts in human clinical trials in breast cancer patients [7]. For example, $\beta$-(1,3)(1,6)-glucan extract from GF induces anti-tumour activity by enhancing hematopoiesis and activating the host immune system [8]. Besides, Z-fraction polysaccharide from GF inhibits tumour growth in BALB/c mice inoculated with colon cancer cell lines [9]. On the other hand, Trametes versicolor also has immunomodulatory effect and specific extracts are used in human cancer therapy in breast cancer prevention. However, the molecular mechanism involved in the antitumor action is still not clear. Recent evidences suggest that polysaccharides extracts can directly affect the viability of human tumour cells, independently of the immune system. For example, polysaccharideenriched extracts from GF induce toxicity and apoptosis in human breast and gastric cancer cells while slightly affecting the growth of normal liver cells $[10,11]$. Moreover, polysaccharides from GF are able to modulate tumour progression in human breast cancer cells by modifying the expression of genes such as IGFBP-7, involved in migration and metastasis [12, 13]. The potential effect of polysaccharides-enriched extracts from GF and TV in human colon carcinoma has not been extensively studied and whether they could play a role in tumour progression and metastasis is also unknown.

Colon tumour cells start to dedifferentiate and acquire enhanced migratory capabilities in order to metastasize. A critical molecular hallmark during dedifferentiation process is the loss of E-cadherin at cell-cell contacts, during a program named epithelial-to-mesenchymal transition (EMT). Loss of E-cadherin is associated to the progression from benign to malignant tumour. Indeed, it was reported that in vitro re-expression of E-cadherin protein in E-cadherin negative tumour cells inhibit cell growth and block invasiveness [14, 15]. On the other hand, cell motility is also associated to the proteolytic activity of matrix metalloproteinases (MMPs). MMPs are a family of zinc-dependent endopeptidases implicated in the proteolytic degradation of the extracellular matrix (ECM) and in the cleavage of cell surface receptors. MMPs play an important role in proliferation, cancer migration and invasion [16]. The two gelatinase MMPs (MMP-2 and MMP-9) are able to degrade collagen type IV playing a critical role in tumour invasiveness [17].

In the present study, we aim to evaluate the anticancer effect of polysaccharide-rich extracts from Trametes versicolor and Grifola frondosa in human colon cancer cells. We particularly show that both extracts inhibit cell proliferation, oncogenic potential, migration and invasion. Moreover, their antitumor action may be due to the increase E-cadherin protein expression and the reduction of MMP-2 activity. Finally, we also show that the combination of 5-Fluorouracil, a common clinical drug used for colorectal cancer, together with the polysaccharide-rich extracts increases cell cytotoxicity suggesting a potential clinical benefit for colon cancer.

\section{Material and methods}

\section{Material}

Fruiting bodies from Grifola frondosa and Trametes versicolor were produced at Hifas da Terra S.L. plant and ground using industrial blenders. The resulting material was extracted with distilled water at a ratio of 1:12 (w/v) for Grifola frondosa and 1:10 $(\mathrm{w} / \mathrm{v})$ for Trametes versicolor at $80^{\circ} \mathrm{C}$ for 30 minutes and filtrated with Whatman No. 1 filter paper. The obtained residue was again extracted applying the same procedure and both filtrates where combined and lyophilized. Grifola frondosa extract presented a total Glucan content of $45 \%(\mathrm{w} / \mathrm{w})$, representing $10.20 \%$ and $34.80 \%$ of a-Glucans and $\beta$-glucans, respectively $(\mathrm{w} / \mathrm{w} ; \beta$-Glucan Assay Kit Yeast \& Mushroom, Megazyme). Grifola frondosa extract is present in several MicoSalud ${ }^{\circledR}$ products of Hifas da Terra S.L. Trametes versicolor extract presented a total Glucan content of $74.30 \%(w / w)$; where a-Glucans and $\beta$-glucans represented $8.7 \%$ and $65.60 \%(w / w)$, respectively. Trametes versicolor extract is present in several MicoSalud® products of Hifas da Terra S.L., including Mico-Corio PSK®. Stock solutions of both extracts were re-suspended in distilled water at 
$50 \mathrm{mg} / \mathrm{ml}$ and stored at $-20^{\circ} \mathrm{C}$. 5-Fluorouracil (5-Fu) was purchased from Sigma-Aldrich.

\section{Cell lines}

Human colon carcinoma LoVo and HT-29 cells were grown with F-12K Medium (Kaighn's Modification of Ham's F-12 Medium) and McCoy's 5a Medium Modified, respectively. Cells were supplemented with penicillin/streptomycin $(50 \mathrm{U} / \mathrm{ml})$ and $10 \%$ heat-inactivated fetal bovine serum and were grown in a humidified incubator at $37^{\circ} \mathrm{C}$ with $5 \% \mathrm{CO}_{2}$. Cells were authenticated with the StemElite ID system (Promega) and monthly tested for mycoplasma to ensure free-contamination cultures.

\section{Cytotoxicity assay}

For cytotoxicity assays, $1 \times 10^{4}$ cells were plated per well into a 96-well plate and cultured during $24 \mathrm{~h}$. Then, cells were treated with 10,50, 100, 250 or $1000 \mu \mathrm{g} / \mathrm{ml}$ of extracts from Trametes versicolor or Grifola frondosa for 24, 48 or $72 \mathrm{~h}$. Viability was measured by using a MTT [3-(4, 5-dimethylthiazol-2-yl)-2, 5-diphenyltetrazolium bromide] colorimetric cell viability assay kit (Sigma Aldrich, St Louis, MO). Cells were treated with 0.5 $\mathrm{mg} / \mathrm{ml}$ of MTT for 3 hours. Then, medium was removed and $100 \mu$ l of DMSO was added to each well and shacked for 10-15 min. Absorbance was measured at 570 and $630 \mathrm{~nm}$ using a Multiskan Plus Reader (Thermo Fisher, MA, USA). Experiments were repeated at least three times and 6 wells were used for each treatment. The half-maximal inhibitory concentration $\left(\mathrm{IC}_{50}\right)$ values were calculated from dose-response curves constructed using GraphPad Prism software. Results are expressed as mean \pm S.D and as fold change compared to untreated cells. To study the effect of the combination of fungal extracts with 5-fluorouracil $(5-\mathrm{Fu})$, cells were treated with different concentrations of 5-Fu $(5,10,100$ and $1000 \mathrm{ng} / \mathrm{ml})$, dissolved in fresh medium, in combination with $250 \mu \mathrm{g} / \mathrm{ml}$ of fungal extracts. After $72 \mathrm{~h}$ of incubation with extracts and 5 -Fu, cells were treated with $0.5 \mathrm{mg} / \mathrm{ml}$ of MTT for 3 hours and cell viability was calculated as previously mentioned.

\section{Proliferation Assay}

For proliferation assays, $1 \times 10^{4}$ LoVo cells were plated per well into a 96-well plate and after $24 \mathrm{~h}$ cells were treated with 10 or $100 \mu \mathrm{g} / \mathrm{ml}$ of different fungal extracts during $48 \mathrm{~h}$. Then, cells were treated with 10 $\mathrm{mM}$ BrdU for $2 \mathrm{~h}$. BrdU incorporation into newly synthesized DNA was measured using a cell proliferation colorimetric immunoassay kit (Roche) according to the manufacturer's instructions. Data are the average of three independent experiments performed six times. Results are expressed as mean \pm S.D and fold change is represented compared to untreated cells.

\section{Soft agar anchorage-independent cell growth}

For soft agar-colony formation assay, $5 \times 10^{3} \mathrm{LoVo}$ cells/well were cultured into a 12-well plate in medium containing $0.375 \%$ low-melting agarose (Sigma Aldrich, St Louis, MO). This agarose was layered over $0.6 \%$ agarose. Each well was allowed to solidify and subsequently covered with $150 \mu$ l culture media in presence or absence of the indicated fungal extracts $(10,100$ or $250 \mu \mathrm{g} / \mathrm{ml})$. Fungal extracts were refreshed every 3 days. After 21 days, cells were fixed and stained with $0.2 \%$ crystal violet in $5 \%$ formalin solution. Colonies were counted in Olympus microscope (magnification 40x) and whole wells were photographed. Experiments were repeated two times plated in triplicates. Results are expressed as mean \pm SD and fold change is represented compared to untreated cells.

\section{Wound healing assay}

Cells were seeded at a high density $\left(7 \times 10^{5}\right.$ cells/ml) in 24-well plates containing Culture-Inserts (Ibidi) and allowed to adhere overnight. Then, cells were treated for $2 \mathrm{~h}$ with $10 \mu \mathrm{g} / \mathrm{ml}$ of mitomycin $\mathrm{C}$ and inserts were removed. Cells were treated with 10 or $100 \mu \mathrm{g} / \mathrm{ml}$ of fungal extracts and wound healing was maintained during 24, 48 and $72 \mathrm{~h}$. Photographs were taken in Nickon Eclipse-Ti microscope (magnification 100x) at the indicated times. Quantification of the distance after cell migration was determined by using ImageJ program, using the MRI Wound Healing Tool. Experiments were repeated at least two times in replicates and results are expressed as mean \pm S.D and fold change is represented compared to untreated cells.

\section{Invasion assay}

For invasion assays, cells were cultured in Ham's F-12K medium with FBS 1\% with the fungi extracts $(10$ or $100 \mu \mathrm{g} / \mathrm{ml})$ for $48 \mathrm{~h}$. Then, LoVo cells $\left(3 \times 10^{5}\right.$ cells/well) were seeded in a cell invasion chamber (Cell invasion assay kit, Chemicon International) in a 24-well plate containing 8- $\mu \mathrm{m}$ pore size polycarbonate membrane covered with a thin layer of extracellular matrix as described [19]. After $72 \mathrm{~h}$, filters were fixed and stained with crystal violet following the manufacturer's specifications. Cells were counted by photographing five-fields in an Olympus microscope (magnification 200x). Experiments were performed in triplicates for each condition and repeated at least two times. Results are expressed as mean \pm S.D and fold induction is represented compared to untreated cells. 


\section{Phase contrast microscopy}

For phase-contrast images, $1 \times 10^{5}$ LoVo cells were plated per well in a 12-well plate and cultured for $24 \mathrm{~h}$ before treatment with 10 or $100 \mu \mathrm{g} / \mathrm{ml}$ of Trametes versicolor or Grifola frondosa extracts for $48 \mathrm{~h}$. Then, cells were fixed with $4 \%$ paraformaldehyde in phosphate-buffered saline (PBS) for $20 \mathrm{~min}$. Phase-contrast images were acquired using Nickon Eclipse-Ti microscope with 100x magnification.

\section{Western blotting}

For protein extraction, $8 \times 10^{5}$ LoVo cells were plated in $60 \mathrm{~mm}$ dishes, and after $24 \mathrm{~h}$ cells were treated with 100 or $250 \mu \mathrm{g} / \mathrm{ml}$ of fungal extracts for 72 $h$. Then, whole cell extracts were prepared for protein extraction as previously described [18]. Briefly, cells were lysed for $30 \mathrm{~min}$ in $0.3 \mathrm{ml}$ of $1 \%$ Triton X-100 lysis buffer (20 mM Tris-HCL [pH 7.5], $150 \mathrm{mM} \mathrm{NaCl}$, and $1 \%$ Triton $\mathrm{X}-100$ ) containing $5 \mu \mathrm{g}$ ml-1 leupeptin, $50 \mathrm{mM}$ phenylmethylsulfonyl fluoride, and 7.2 trypsin inhibitor units for aprotinin. After centrifugation at $14000 \mathrm{~g}$ for $10 \mathrm{~min}$, twenty micrograms of the supernatants were loaded in $10 \%$ polyacrilamide SDS-PAGE. Western blotting was performed as previously described [19]. For western blotting, antibodies used are: monoclonal E-cadherin antibody (BD 610182), and monoclonal GAPDH antibody (Invitrogen, 39-8600). Experiments were repeated at least three times. Images were quantified by densitometry and results are expressed as mean \pm S.D and fold induction is represented compared to untreated cells.

\section{Gelatin zymography}

Zymogram technique was used to detect matrix metalloproteinase 2 and 9 (MMP-2 and MMP-9) activity. Cells were seeded in $60 \mathrm{~mm}$ dishes and incubated with 100 or $250 \mathrm{mg} / \mathrm{ml}$ of fungi extracts for $72 \mathrm{~h}$. The last $24 \mathrm{~h}$, cells were grown in $1 \mathrm{ml}$ of serum-free medium. Medium was collected, centrifuged and loaded, using cell number for normalization. Samples were run in a $10 \%$ polyacrylamide gels containing gelatin $(0.05 \%)$ under non-reducing conditions. SDS was removed by extensively washing in $2.5 \%$ Triton X-100 and metalloproteinase activity was reactivated by incubating the gel in a buffer containing $40 \mathrm{mM}$ Tris- $\mathrm{HCl} \mathrm{pH}$ 7,5; 0,1 $\mathrm{M}$ benzamidine (SIGMA) and 10 $\mathrm{mM} \mathrm{CaCl}$, for $72 \mathrm{~h}$. The gel was stained with Coomassie Blue R250 in a $10 \%$ acetic acid, 50\% methanol solution overnight, and then, distained in $10 \%$ acetic acid, 50\% methanol, until bands were clearly visible. Protease activity appeared as clear bands against a blue background where MMP-2 or MMP-9 has digested gelatin substrate. Gels were photographed and quantified with Amersham Imager 600 equipment. Experiment was repeated three times and quantification is expressed as mean \pm SD.

\section{Statistical analysis}

Statistical significance was determined with GraphPad Prism software applying ANOVA or Kruskal-Wallis test. Shapiro-Wilk test was used to check a normal distribution and Levene test to determine the equality of variances. Results are expressed as means \pm SD. Significance of the Student $t$-test among the experimental groups indicated in the figures is shown as ${ }^{*} p<0.05,{ }^{* *} p<0.01$ and ${ }^{* * *} p<0.001$.

\section{Results}

\section{Effect of TV and GF extracts on cell viability and proliferation in human colon cancer cells}

To determine the effect of TV and GF fungal extracts on cancer cell viability, two different human colon cancer cell lines were selected. LoVo colon cells, derived from a metastatic site, and HT-29, a colorectal adenocarcinoma cell line with an epithelial morphology. Cells were treated at different concentrations ranging from $10 \mu \mathrm{g} / \mathrm{ml}$ to $250 \mu \mathrm{g} / \mathrm{ml}$ for $24 \mathrm{~h}, 48 \mathrm{~h}$ and $72 \mathrm{~h}$. TV extract did not show any significant effect on cell viability after $24 \mathrm{~h}$ of treatment in LoVo cells. However, slightly reduction was detected after $48 \mathrm{~h}$, and significantly decrease was shown after $72 \mathrm{~h}$, up to $40 \%$ reduction at a lower concentration $(10 \mu \mathrm{g} / \mathrm{ml})$, (Figure 1A). On the other hand, no significant effect was detected while treating HT-29 cells with TV extracts after $24 \mathrm{~h}, 48 \mathrm{~h}$ and $72 \mathrm{~h}$ (Figure 1B). GF treatment showed its inhibitory effect on LoVo cell viability at earlier times than TV extract by using higher concentrations $(100 \mu \mathrm{g} / \mathrm{ml}$ and 250 $\mu \mathrm{g} / \mathrm{ml})$. After $72 \mathrm{~h}$ of GF treatment, markedly reduction on cell viability was seen at a lower concentration ( $40 \%$ reduction compared to untreated cells using $10 \mu \mathrm{g} / \mathrm{ml}$ ), (Figure 1C). Finally, the most prominent cytotoxicity effect was observed using GF extract in HT-29 cells. In these cells, at a low concentration of $50 \mu \mathrm{g} / \mathrm{ml}$ GF extract, it was already observed a strong decrease after $24 \mathrm{~h}, 48 \mathrm{~h}$ and $72 \mathrm{~h}$. This inhibitory effect on cytotoxicity reached up to $60-70 \%$ reduction after $72 \mathrm{~h}$ of GF treatment with 100 $\mu \mathrm{g} / \mathrm{ml}$ concentration, and similar results were observed with the concentration of $250 \mu \mathrm{g} / \mathrm{ml}$ at any of the tested times ( $24 \mathrm{~h}, 48 \mathrm{~h}$ and $72 \mathrm{~h}$ ) (Figure 1D). Moreover, no cytotoxicity effect of the TV and GF extracts was detected in a non-tumorigenic epithelial MDCK cell lines (data not shown). The $\mathrm{IC}_{50}$ values for TV and GF were determined for each colon cancer cell lines (Table 1). Taken together our results show a more potent cytotoxicity effect of GF extracts 
compared to TV extracts in LoVo and HT-29 colon cancer cell lines.

Table 1. IC 50 values for both extracts were calculated and indicated for Lovo and HT29 cell lines.

\begin{tabular}{lccc}
\hline LoVo & \multicolumn{3}{c}{$\mathrm{IC}_{50}(\mu \mathrm{g} / \mathrm{ml})$} \\
& - & $72 \mathrm{~h}$ \\
T. versicolor & 934,82 & 224,02 \\
G. frondosa & & 127,12 \\
& & $\mathrm{IC}_{50}(\mu \mathrm{g} / \mathrm{ml})$ & \\
HT-29 & $24 \mathrm{~h}$ & & $72 \mathrm{~h}$ \\
& - & - \\
T. versicolor & 44,09 & 21,07 \\
G. frondosa & & \\
\hline
\end{tabular}

To analyse the effects of TV and GF extracts in colon cancer growth, LoVo cells were treated with increasing concentrations $(10 \mu \mathrm{g} / \mathrm{mg}$ and $100 \mu \mathrm{g} / \mathrm{ml})$ of each extract for $48 \mathrm{~h}$ and then proliferation was measured by BrdU assay. Quantification of BrdU incorporation confirmed that exposure to lower concentrations $(10 \mu \mathrm{g} / \mathrm{ml})$ of $\mathrm{TV}$ resulted in a significantly growth inhibition (up to $45 \%$ compared to untreated cells). Moreover, treatment with 10 $\mu \mathrm{g} / \mathrm{ml}$ of GF extract produced up to $50-60 \%$ inhibition, while this inhibitory effect was increased up to $80 \%$ inhibition at $100 \mu \mathrm{g} / \mathrm{ml}$ of GF extract (Figure 1E). Our results showed a stronger anti-proliferative effect of GF extract compared to TV extract in Lovo cells. Interestingly, effects of both fungal extracts are more markedly on proliferation than on toxicity, therefore exposure to lower concentrations resulted in a growth inhibition, avoiding cytotoxicity effect.

\section{Effect of TV and GF extracts on anchorage-independent cell growth}

Given the observed effect in cytotoxicity and proliferation of the fungi extracts on colon cancer cells, we wondered whether they could have a potential role on the inhibition of tumour progression. The ability of cancer cells to survive and proliferate in the absence of a solid substrate is an important characteristic for the acquisition of an invasive and metastatic phenotype. By using soft agar growth assays, we examined the effect of the TV and GF extracts on colony formation in LoVo cells. As shown in Figure 2, both extracts significantly reduced colony formation induced by LoVo tumour cells. The effect was even detected at the lowest concentration tested of $10 \mu \mathrm{g} / \mathrm{ml}$ for both extracts. These results indicate that TV and GF extracts reduce anchorageindependent cell growth, thus reducing the oncogenic potential in colon cancer cells.

\section{Effect of TV and GF extracts on cell migration and invasion}

Cell migration and invasion capabilities of tumour cells are important features of malignant tumours during tumour progression and metastasis. We examined whether TV and GF extracts can inhibit cell migration in LoVo cells by using wound-healing assays. Results showed $40 \%$ and $20 \%$ of wound closure in LoVo cells after treatment with GF extracts during $48 \mathrm{~h}$ and $72 \mathrm{~h}$, respectively (Figure 3A). Concentrations of $10 \mu \mathrm{g} / \mathrm{mg}$ and $100 \mu \mathrm{g} / \mathrm{ml}$ of TV extracts reduce around $50 \%$ of the wound closure after $48 \mathrm{~h}$. Similar results were obtained after GF

\section{A}

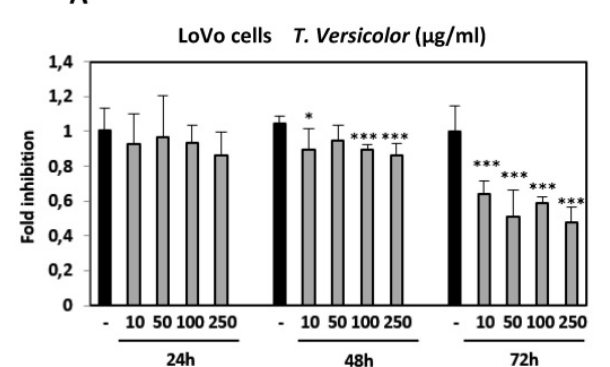

$$
c
$$

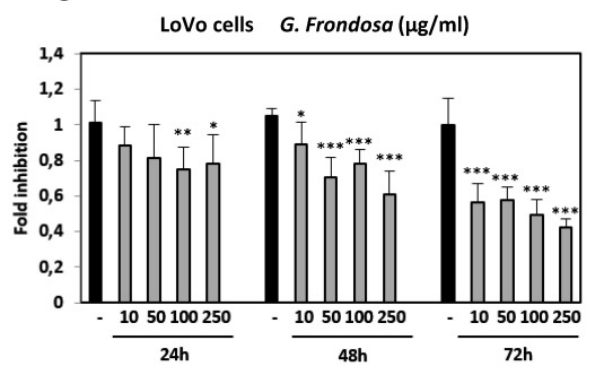

B

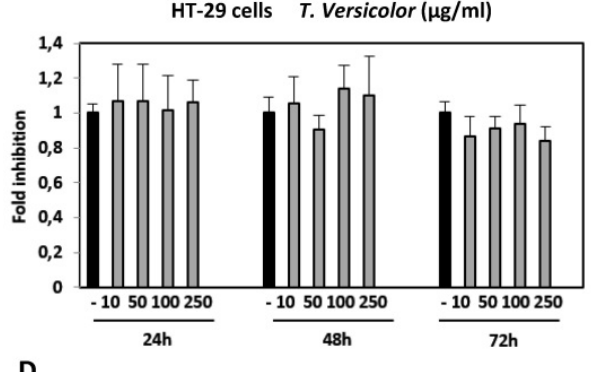

D

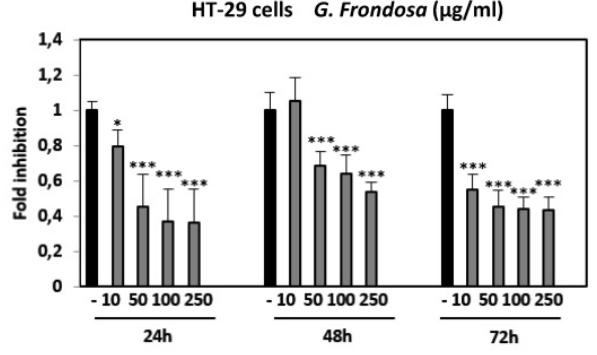

E

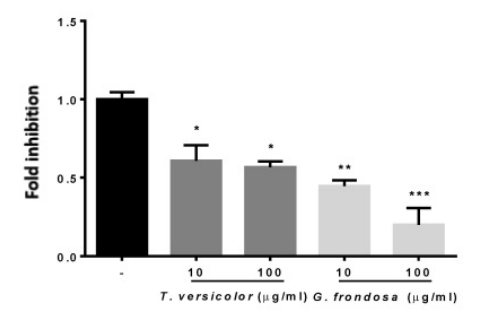

Fig 1. Effect of Trametes versicolor and Grifola frondosa extracts on viability of colon cancer cells. LoVo (A and C) and HT-29 cells (B and D) were treated with Trametes versicolor and Grifola frondosa extracts for 24,48 and $72 \mathrm{~h}$ and MTT activity was determined. (E) Effect of fungi extracts on cell proliferation in LoVo cells was determined by a BrdU assay as described in Material and Methods. Data are the means \pm SD of three independent experiments $\left({ }^{*} p<0.05, * * p<0.01 * * p<0.001\right)$ 
treatment during $48 \mathrm{~h}$ treatment with $10 \mu \mathrm{g} / \mathrm{mg}$ concentration (Figure 3A). Based on the observation that fungal extracts significantly inhibited LoVo cells migration, it is reasonable to hypothesize whether TV and GF may also affect cell invasion. To investigate the possible effect of the extracts on the invasive capacity, an invasion assays in LoVo cells was performed. It was previously reported that LoVo cells were able to cross through a matrigel matrix [20]. Our

A

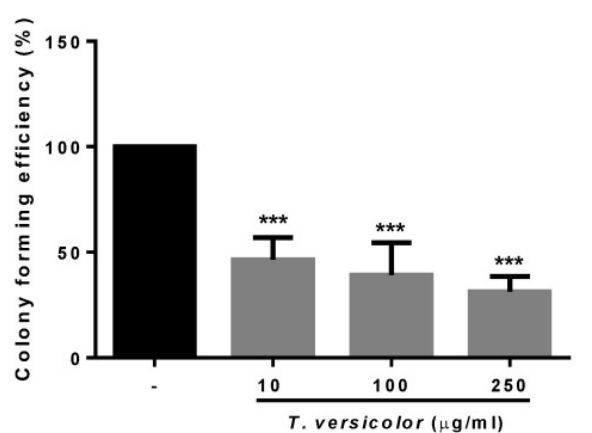

results clearly showed that TV and GF extracts significantly attenuated the invasion capability of LoVo colon cancer cells (Figure 3B) after treatment with 10 or $100 \mu \mathrm{g} / \mathrm{mg}$ of both extracts. These results pointed out that TV and GF extracts inhibited cell migration and invasion in LoVo cells at non-cytotoxic dosage $(10 \mu \mathrm{g} / \mathrm{mg})$, suggesting that both extracts might be potent and multiple functional agents to treat colon cancer progression and metastasis.

B

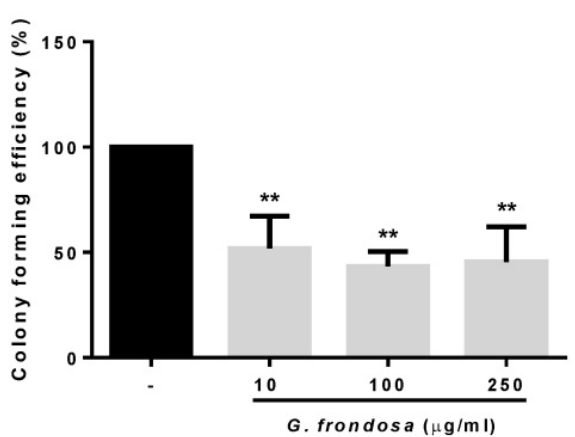

Fig 2. Effect of TV and GF extracts on anchorage-independent cell growth in soft agar. LoVo cells colonies were treated with Trametes versicolor (A) and Grifola frondosa (B) extracts for 21 days and the colony formation was determined by manual counting. Data are represented by the means \pm SD of two independent experiments $\left({ }^{*} p<0.05, * * p<0.01 * * p<0.001\right)$

B
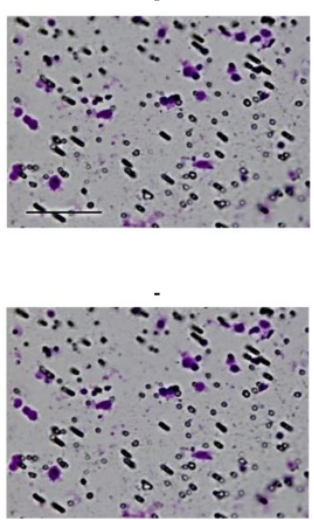

A

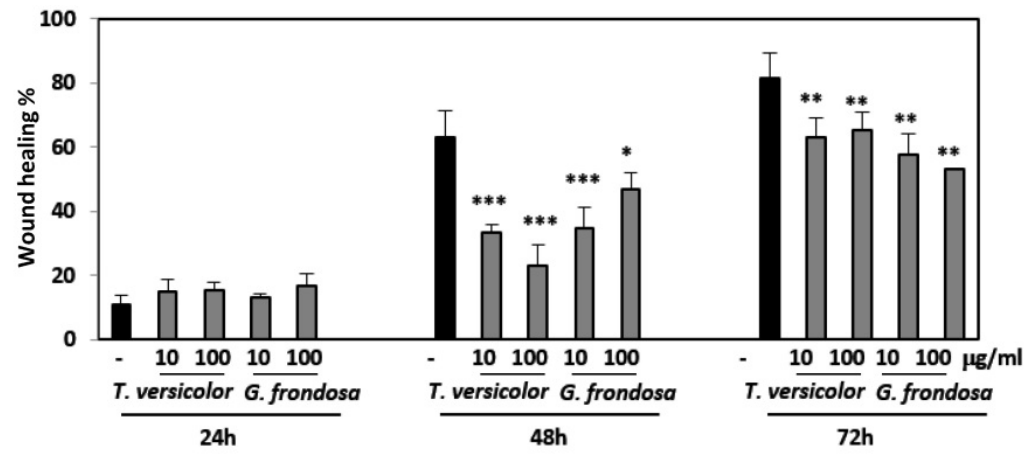

T. Versicolor $(\mu \mathrm{g} / \mathrm{ml})$

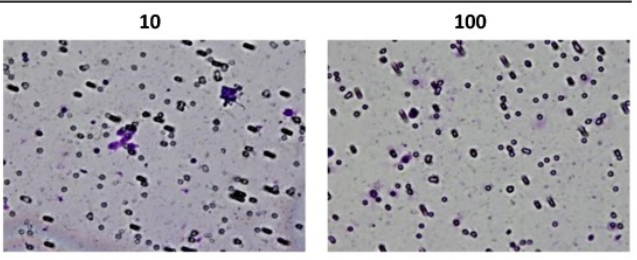

G. Frondosa $(\mu \mathrm{g} / \mathrm{ml})$
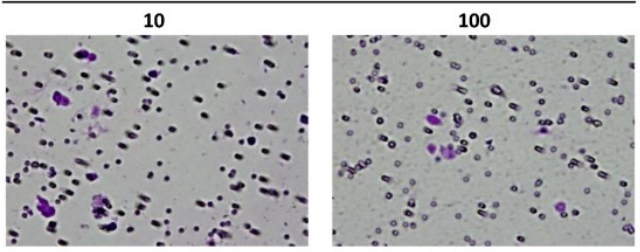

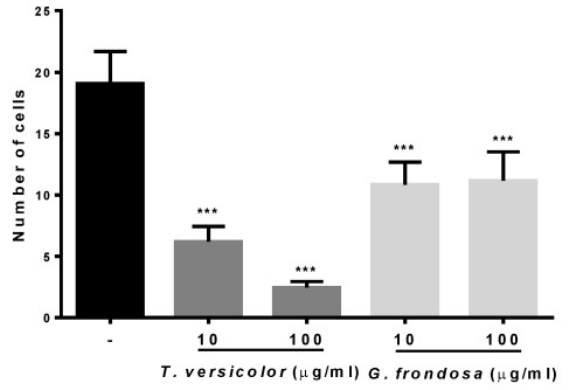

Fig 3. Effect of Trametes versicolor and Grifola frondosa extracts on cell migration and invasion in LoVo colon cancer cells. (A) LoVo cells were pre-treated for $2 \mathrm{~h}$ with mitomycin $\mathrm{C}$ to block proliferation and wound healing assay was followed for 3 days in presence or absence of the indicated concentrations of TV and GF extracts. Wound closure was quantified using Imagel program. Data are represented by the means \pm SD in duplicates from two independent experiments. (B) Effect of TV and GF extracts on cell invasion in LoVo colon cancer cells. Cells were treated with the indicated concentrations of extracts for 48h. Cells were trypsinized and seeded in an invasion chamber as described in the Material and Methods. Migrated cells were stained, photographed and counted with a microscope at $200 X$. Scaled bar $627 \mu \mathrm{m}$. Data are the means \pm SD of three independent experiments $\left(* \mathrm{p}<0.05,{ }^{*} \mathrm{p}<0.01 * * \mathrm{p}<0.001\right)$. 


\section{Effect of TV and GF extracts on E-cadherin protein expression and MMP-2 activity}

Next, we decided to study the possible molecular mechanisms by which migration and invasion could be regulated. To this end, first it was analysed the effect of TV and GF extracts on cellular morphology by phase-contrast microscopy. As shown in Figure 4, a more prominent epithelial morphology was observed in LoVo cells under TV and GF treatment (Figure 4A and B, respectively) compared to the fibroblast phenotype observed in non-treated cell. This morphology switch, from fibroblast to epithelial phenotype was accompanied by an increase in cell-cell adhesions, and a decrease number of membrane protrusions (Figure 4A and B, respectively). In addition, we evaluated the effect of the extracts on E-cadherin expression. E-cadherin is one of the best characterize cell adhesion molecules between epithelial cells, important for the establishment of tight cell-cell contacts. Indeed, loss of E-cadherin is lost during carcinoma development. The dedifferentiation process is linked to carcinoma-associated EMT, a crucial event for cellular migration and invasion of tumour cells. Moreover, E-cadherin loss is associated to tumour progression, invasion and metastasis. Then, we analysed E-cadherin protein expression by western blotting (Figure 4C, upper panel and Figure S1) and a statistical significant increase of E-cadherin protein expression was detected after treatment with TV and GF extracts in LoVo cells (Figure 4C, lower panel). Next, we tested whether fungal extracts may suppress metalloproteinase activity. It is known that the degradation of the extracellular matrix is a crucial event during tumour invasion and metastasis. The gelatinase MMP-2 and MMP-9 are two members of the MMP family that have been extensively studied given their consistent association with tumour invasion and metastasis. MMP-2 and MMP-9 activity was measured by a zymogram assay and a significantly decrease on MMP-2 activity was detected after treatment with both fungal extracts (Figure 4D, upper panel and Figure S2). Although both fungal extracts were able to induce a strong reduction of MMP-2 activity, this reduction was more prominent using GF extract, reaching up to $60 \%$ decrease of MMP-2 activity with the lowest concentration tested at $100 \mu \mathrm{g} / \mathrm{mg}$ (Figure $4 \mathrm{D}$, lower panel).

\section{TV and GF extracts increases the effect of 5-fluorouracil}

5-fluorouracil (5-Fu) is a commonly used cytotoxic agent to treat colon cancer patients. The combination of 5-fluorouracil-based chemotherapy with other agents, such as natural products, has been extensively studied. However, the optimal combination regimen has not been determined. We examined the cytotoxicity effect of TV and GF fungal extracts in combination with 5-FU in LoVo cells. LoVo cells were treated with increasing concentrations of $5-\mathrm{Fu}$, alone or in combination with fungal extracts. MTT cytotoxicity assays showed an increase cytotoxicity effect at the lowest concentrations tested of $5-\mathrm{Fu}(0,005 \mu \mathrm{g} / \mathrm{ml})$ in combination with $250 \mu \mathrm{g} / \mathrm{ml}$ of TV or GF fungal extracts. Indeed, the combination of 5-Fu with TV extracts was more evident (Figure 5). These results suggest a possible benefit of these fungal extracts in combination with 5-fluorouracil-based chemotherapy in colon cancer.
A

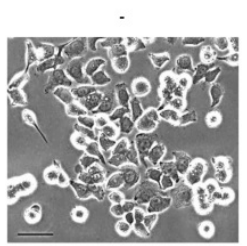

B

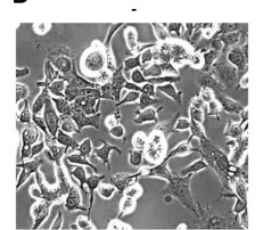

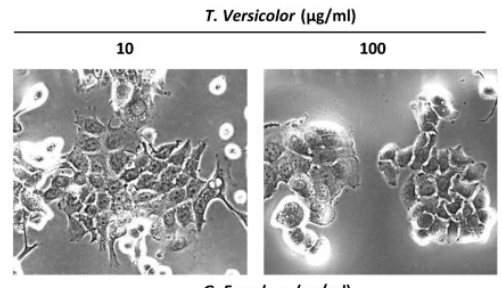

G. Frondosa $(\mu \mathrm{g} / \mathrm{ml})$

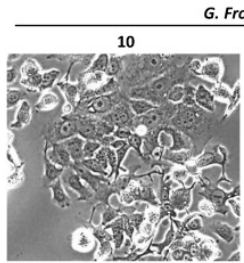

C
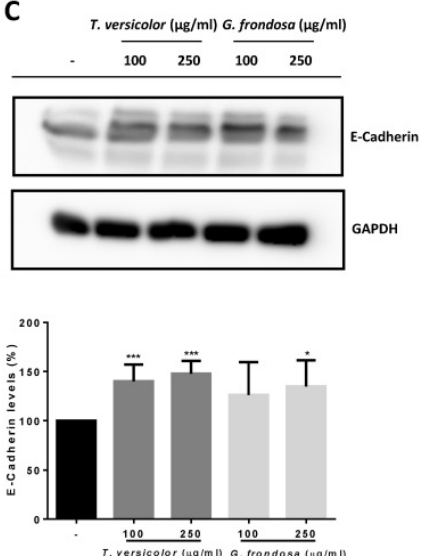

D
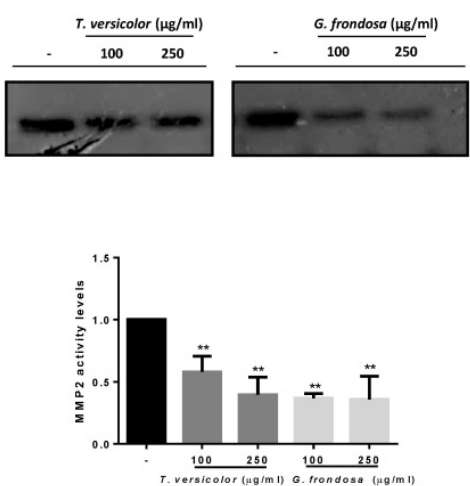

Fig 4. Effect of Trametes versicolor and Grifola frondosa extracts on cell morphology and invasion-related proteins. (A) Effect of TV extract on cell morphology of LoVo cells. (B) Effect of GF extract on cell phenotype in LoVo cells. (A and B) Phase-contrast microscopy images were taken after $48 \mathrm{~h}$ treatment with $10 \mu \mathrm{gg} / \mathrm{mg}$ or $100 \mathrm{\mu g} / \mathrm{mg}$ of the indicated extracts. Scale bar $100 \mu \mathrm{m}$. (C) Effect of TV and GF extracts on E-cadherin protein expression. LoVo cells were treated with fungal extracts for $72 \mathrm{~h}$ and E-cadherin expression was determined by western-blot (upper panel). Western blot data are representative of three independent experiments and quantification by densitometry was represented (lower panel) (D) Effect of TV and GF extracts on the activity of metalloproteases in LoVo colon cancer cells was determined by zymogram assay. LoVo cells were treated with the indicated concentrations of the indicated fungal extracts for $72 \mathrm{~h}$ and MMP2 activity is shown in upper panel. Quantification of three independent experiments is represented in the lower panel. Data are the means \pm SD of three independent experiments $\left({ }^{*} p<0.05, *^{*} p<0.01 * * p<0.001\right)$. 
A

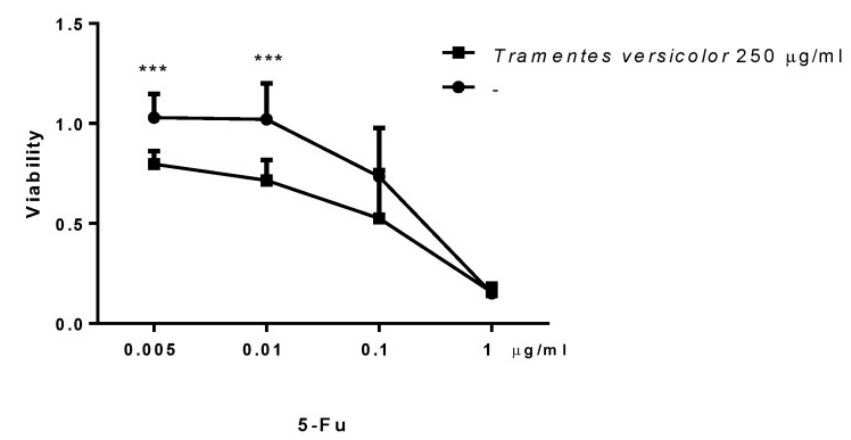

B

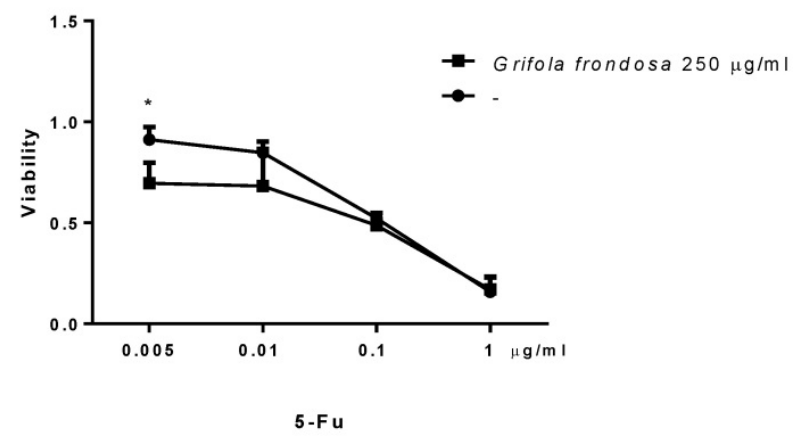

Fig 5. Effect of Trametes versicolor and Grifola frondosa extracts in combination with 5-Fluorouracil on cytoxicity in LoVo colon cancer cells. (A) LoVo cells were treated with the indicated concentration of Trametes versicolor extract in combination with increasing concentrations of 5-Fluorouracil. (B) LoVo cells were treated with the indicated concentration of Grifola frondosa extract in combination with increasing concentrations of 5-Fluorouracil. Cell viability was measured as indicated in material and methods. Data are represented as means \pm SD of three independent experiments $\left({ }^{*} p<0.05, *^{*} p<0.01 *^{* *} p<0.001\right)$.

\section{Discussion}

Basidiomycete mushrooms have been shown to exert therapeutic anticancer properties, primarily because they contain a number of biologically active compounds. This effect is mainly linked to the presence of polysaccharides and their derivatives. Certain species of medicinal mushrooms produce bioactive compounds with antitumor activity that could work as adjuvants together with cancer chemotherapy. Indeed, polysaccharide-rich extracts from Grifola frondosa and Trametes versicolor species have already shown to play relevant clinical benefits in cancer patients [21, 22]. Recent evidence suggested a direct antitumor effect of polysaccharides-extracts in cancer cells independently of its action on the immune system. In this study, we used polysaccharide-rich extracts from GF and TV in order to investigate the possible molecular mechanism involved in the antitumor action in human colon cancer cell lines. Our results show that polysaccharide-rich extracts from GF and TV were capable not only to directly inhibit tumour cell proliferation in human colon carcinoma cells but also to inhibit anchorage-independent cell growth, cell migration and invasion, which are characteristics that facilitates the metastatic process in multiple carcinoma types [14]. Both extracts were able to induce an epithelial phenotype by increasing epithelial E-cadherin proteins marker, while the Vimentin mesenchymal marker was almost not detected in LoVo cells. Importantly, loss of E-cadherin during the acquisition of invasive characteristics has been linked to the metastatic process of colon tumour cells $[23,24]$. In addition, we also observed that both extracts significantly decreased MMP-2 activity. Importantly, MMP-2 degrade extracellular matrix and promote cell growth and invasion in colorectal cancer and low levels of MMP-2 are associated with survival in breast carcinoma [25-27]. It has been reported that
MMPs activity may be regulated at different levels such as transcription, mRNA half-life, secretion, localization, regulation by proteolytic cleavage, proteinase inhibitors or post-traslational modification (such as phosphorylation, or acetylation). However, further studies are needed to determine the most probable mechanism by which MMP-2 activity is regulated by these two TV and GF extracts. The fact that both extracts are able to decrease MMP-2 activity and increase E-cadherin protein levels may explain, at least in part, the mechanism by which they may inhibit cell migration and invasiveness in human colon cancer cells. However, other previous studies using TV extracts were reported to have different effect. For example, a reduction in MMP-9 activity but no changes for MMP-2 activity was observed by using aqueous extracts from TV in mouse mammary carcinoma [28]. On the other hand, an inhibition of both enzymes was detected by using protein-bound polysaccharide-K extracted from TV in human pancreatic and gastric cancer cell lines [29]. Interestingly in both studies it is shown how anti-migratory activity was not linked to anti-proliferative activity. In this study, the developed polysaccharides-rich extracts from GF and TV showed an anti-proliferative and anti-migratory action in human colon cancer cells, further supporting the potential benefit of the extracts in human colon cancer treatment.

Not many studies have reported a direct effect of polysaccharides-rich extracts from GF and TV in colon cancer cells and, in general, the reported investigations were performed in murine cancer cells with different results. For example, a heteropolysaccharide (MZF) from GF did not affect cell proliferation in vitro using mouse colon-26 cells [30]. On the other hand, although TV polysaccharide-rich extracts were shown to decrease cell viability in a human colon carcinoma cell line by 
inhibiting apoptosis [31], no effect on cell proliferation was observed in human pancreatic and gastric cancer cell lines [29]. A water extract from TV, similar to the developed in the present study, did not show cytotoxicity effect in mouse mammary carcinoma even at a higher concentration $(2 \mathrm{mg} / \mathrm{mL})$ [28]. It is important to note that in this reported study, polysaccharide content was only $8.34 \%(\mathrm{w} / \mathrm{w})$ while in our study a higher-relative fraction of bioactive-polysaccharides was obtained (45 to $74 \%$ in glucans content). These differences may explain the different cytotoxicity effect in different cell lines, butalso it may be influenced by the fruit body composition or the extraction procedures performed. Our data suggest that the extracts obtained in the present study may affect cancer cell proliferation and reinforces the critical importance of the production techniques used to observe these effects in cancer cells. Finally, the combination of 5-fluorouracil together with each polysaccharide-rich extracts increases cell cytotoxicity. These data suggest a potential adjuvant role for these extracts together with certain chemotherapeutic agents such as 5-Fu. Taken all together, the potential antitumor effect of the polysaccharide-rich GF and TV extracts in other human cancer cells and in vivo model systems awaits to be elucidated. Moreover, future clinical trials are needed to further evaluate safety and efficacy of these two newly developed GF and TV extracts.

\section{Supplementary Material}

Supplementary figures.

http://www.medsci.org/v16p0231s1.pdf

\section{Acknowledgments}

This work has been supported by the Center for Industrial Technological Development (CDTI, Interconecta Program, 2015), co-funded by the Fondo Europeo de Desarrollo Regional (FEDER) "A way of Making Europe") and by the companies CZ Veterinaria, S.A. and Hifas da Terra S.L. Roca-Lema has been supported by post-specialization fellowship from Fundación Profesor Novoa Santos, Diaz-Diaz has been supported by FPU contract (FPU014/02837) from Ministerio de Educación Cultura y Deporte from Spain and Casas-Pais has been supported by a predoctoral contract (IN606A-2017/013) from Axencia Galega de Innovación (GAIN)-Consellería de Economía, Empleo e Industria from Xunta de Galicia, Spain.

\section{Competing Interests}

The authors have declared that no competing interest exists.

\section{References}

1. Siegel RL, Miller KD, Jemal A. Cancer statistics, 2018. CA Cancer J Clin. 2018;68(1):7-30.

2. Jemal A, Ward EM, Johnson CJ, Cronin KA, Ma J, Ryerson B, et al. Annual Report to the Nation on the Status of Cancer, 1975-2014, Featuring Survival. J Natl Cancer Inst. 2017;109(9)

3. Zheng H, Kang Y. Multilayer control of the EMT master regulators. Oncogene. 2014;33(14):1755-63.

4. Guggenheim AG, Wright KM, Zwickey HL. Immune Modulation From Five Major Mushrooms: Application to Integrative Oncology. Integr Med (Encinitas). 2014;13(1):32-44.

5. Shnyreva AV, Shnyreva AA, Espinoza C, Padrón JM, Trigos Á. Antiproliferative Activity and Cytotoxicity of Some Medicinal Wood-Destroying Mushrooms from Russia. Int $\mathrm{J}$ Med Mushrooms. 2018;20(1):1-11.

6. Kim M, Jee SC, Sung JS, Kadam AA. Anti-proliferative applications of laccase immobilized on super-magnetic chitosan-functionalized halloysite nanotubes. Int J Biol Macromol. 2018;118(Pt A):228-37.

7. Deng G, Lin H, Seidman A, Fornier M, D'Andrea G, Wesa K, et al. A phase I/II trial of a polysaccharide extract from Grifola frondosa (Maitake mushroom) in breast cancer patients: immunological effects. J Cancer Res Clin Oncol. 2009;135(9):1215-21.

8. Masuda Y, Inoue M, Miyata A, Mizuno S, Nanba H. Maitake beta-glucan enhances therapeutic effect and reduces myelosupression and nephrotoxicity of cisplatin in mice. Int Immunopharmacol. 2009;9(5):620-6.

9. Masuda $\mathrm{Y}$, Ito $\mathrm{K}$, Konishi $\mathrm{M}$, Nanba $\mathrm{H}$. A polysaccharide extracted from Grifola frondosa enhances the anti-tumor activity of bone marrow-derived dendritic cell-based immunotherapy against murine colon cancer. Cancer Immunol Immunother. 2010;59(10):1531-41.

10. Cui FJ, Li Y, Xu YY, Liu ZQ, Huang DM, Zhang ZC, et al. Induction of apoptosis in SGC-7901 cells by polysaccharide-peptide GFPS1b from the cultured mycelia of Grifola frondosa GF9801. Toxicol In Vitro. 2007;21(3):417-27.

11. Zhang Y, Sun D, Meng Q, Guo W, Chen Q. Grifola frondosa polysaccharides induce breast cancer cell apoptosis via the mitochondrial-dependent apoptotic pathway. Int J Mol Med. 2017;40(4):1089-95.

12. Alonso EN, Orozco M, Eloy Nieto A, Balogh GA. Genes related to suppression of malignant phenotype induced by Maitake D-Fraction in breast cancer cells. J Med Food. 2013;16(7):602-17.

13. Alonso EN, Ferronato MJ, Gandini NA, Fermento ME, Obiol DJ, López Romero A, et al. Antitumoral Effects of D-Fraction from Grifola Frondosa (Maitake) Mushroom in Breast Cancer. Nutr Cancer. 2017;69(1):29-43.

14. Aparicio LA, Blanco M, Castosa R, Concha Á, Valladares M, Calvo L, et al. Clinical implications of epithelial cell plasticity in cancer progression. Cancer Lett. 2015;366(1):1-10.

15. Wong SHM, Fang CM, Chuah LH, Leong CO, Ngai SC. E-cadherin: Its dysregulation in carcinogenesis and clinical implications. Crit Rev Oncol Hematol. 2018;121:11-22.

16. Gialeli C, Theocharis AD, Karamanos NK. Roles of matrix metalloproteinases in cancer progression and their pharmacological targeting. FEBS J. 2011;278(1):16-27.

17. Egeblad M, Werb Z. New functions for the matrix metalloproteinases in cancer progression. Nat Rev Cancer. 2002;2(3):161-74.

18. Díaz-Díaz A, Casas-Pais A, Calamia V, Castosa R, Martinez-Iglesias O, Roca-Lema D, et al. Proteomic Analysis of the E3 Ubiquitin-Ligase Hakai Highlights a Role in Plasticity of the Cytoskeleton Dynamics and in the Proteasome System. J Proteome Res. 2017;16(8):2773-88.

19. Rodriguez-Rigueiro T, Valladares-Ayerbes M, Haz-Conde M, Aparicio LA, Figueroa A. Hakai reduces cell-substratum adhesion and increases epithelial cell invasion. Bmc Cancer. 2011;11.

20. Ji Q, Liu X, Han Z, Zhou L, Sui H, Yan L, et al. Resveratrol suppresses epithelial-to-mesenchymal transition in colorectal cancer through TGF- $\beta 1 /$ Smads signaling pathway mediated Snail/E-cadherin expression. BMC Cancer. 2015;15:97.

21. Eliza WL, Fai CK, Chung LP. Efficacy of Yun Zhi (Coriolus versicolor) on survival in cancer patients: systematic review and meta-analysis. Recent Pat Inflamm Allergy Drug Discov. 2012;6(1):78-87.

22. Kodama N, Komuta K, Nanba H. Can maitake MD-fraction aid cancer patients? Altern Med Rev. 2002;7(3):236-9.

23. Nieto MA. Epithelial plasticity: a common theme in embryonic and cancer cells. Science. 2013;342(6159):1234850.

24. Ye X, Weinberg RA. Epithelial-Mesenchymal Plasticity: A Central Regulator of Cancer Progression. Trends Cell Biol. 2015;25(11):675-86.

25. Talvensaari-Mattila A, Pääkkö P, Turpeenniemi-Hujanen T. Matrix metalloproteinase-2 (MMP-2) is associated with survival in breast carcinoma. Br J Cancer. 2003;89(7):1270-5.

26. Dong W, Li H, Zhang Y, Yang H, Guo M, Li L, et al. Matrix metalloproteinase 2 promotes cell growth and invasion in colorectal cancer. Acta Biochim Biophys Sin (Shanghai). 2011;43(11):840-8.

27. López-Otín C, Matrisian LM. Emerging roles of proteases in tumour suppression. Nat Rev Cancer. 2007;7(10):800-8

28. Luo KW, Yue GG, Ko CH, Lee JK, Gao S, Li LF, et al. In vivo and in vitro anti-tumor and anti-metastasis effects of Coriolus versicolor aqueous extract on mouse mammary 4T1 carcinoma. Phytomedicine. 2014;21(8-9):1078-87. 
29. Zhang H, Morisaki T, Matsunaga H, Sato N, Uchiyama A, Hashizume K, et al. Protein-bound polysaccharide PSK inhibits tumor invasiveness by down-regulation of TGF-beta1 and MMPs. Clin Exp Metastasis. 2000;18(4):343-52.

30. Masuda Y, Matsumoto A, Toida T, Oikawa T, Ito K, Nanba H. Characterization and antitumor effect of a novel polysaccharide from Grifola frondosa. J Agric Food Chem. 2009;57(21):10143-9.

31. Satoh Y, Goi T, Nakazawa T, Kimura Y, Hirono Y, Katayama K, et al. Polysaccharide $K$ suppresses angiogenesis in colon cancer cells. Exp Ther Med. 2012;4(3):370-4. 